\title{
Impact of donor-recipient age on cardiac transplant survival. Subanalysis of the Spanish Heart Transplant Registry
}

Impacto de la edad del donante-receptor en la supervivencia al trasplante cardiaco. Subanálisis del Registro Español de Trasplante Cardiaco

\author{
Raquel López-Vilella ${ }^{\mathrm{a}}$, Francisco González-Vílchez ${ }^{\mathrm{b}}$, María G. Crespo-Leiro ${ }^{\mathrm{c}, \mathrm{d}, \mathrm{e}, \mathrm{f}}$, \\ Javier Segovia-Cuberog, Manuel Cobo ${ }^{\mathrm{b}}$, Juan Delgado-Jiménez ${ }^{\mathrm{h}, \mathrm{i}, \mathrm{j}}$, José María \\ Arizón del Prado ${ }^{\mathrm{k}}$, Manuel Martínez-Sellés ${ }^{\mathrm{i}, \mathrm{j}, \mathrm{l}, \mathrm{m}}$, José Manuel Sobrino Márquez ${ }^{\mathrm{n}}$, \\ Sonia Mirabet-Pérez ${ }^{0}$, José González-Costell ${ }^{\mathrm{o}, \mathrm{p}}$, Félix Pérez-Villa ${ }^{\mathrm{q}}$, José Luis \\ Lambert-Rodríguez ${ }^{\mathrm{r}}$, Gregorio Rábago-Aracil's, María Teresa Blasco-Peirót, Luis \\ de la Fuente-Galán ${ }^{u}$, Iris Garrido-Bravovo , Déborah Otero ${ }^{\text {e,d,f,w }}$, Luis Almenar- \\ Bonet $^{\mathrm{a}, \mathrm{j}, \mathrm{x}}$.
}

a Unidad de Insuficiencia Cardiaca y Trasplante, Servicio de Cardiología, Hospital Universitario y Politécnico La Fe, Valencia, Spain

b Servicio de Cardiología, Hospital Universitario Marqués de Valdecilla, Santander, Cantabria, Spain c Servicio de Cardiología, Complexo Hospitalario Universitario A Coruña (CHUAC), A Coruña, Spain d Centro de Investigación Biomédica en Red Enfermedades Cardiovaculares, CIBERCV, A Coruña, Spain e Instituto de Investigación Biomédico A Coruña (INIBIC), A Coruña, Spain

$f \quad$ Universidade da Coruña (UDC), A Coruña, Spain

g Servicio de Cardiología, Hospital Universitario Puerta de Hierro de Majadahonda, Majadahonda, Madrid, Spain

h Servicio de Cardiología, Hospital Universitario 12 de Octubre, Madrid, Spain Facultad de Medicina, Universidad Complutense de Madrid, Madrid, Spain Centro de Investigación Biomédica en Red Enfermedades Cardiovaculares, CIBERCV, Madrid, Spain Servicio de Cardiología, Hospital Universitario Reina Sofía, Córdoba, Spain l Servicio de Cardiología, Hospital Universitario Gregorio Marañón, Madrid, Spain

m Universidad Europea de Madrid, Madrid, Spain

n Servicio de Cardiología, Hospital Universitario Virgen del Rocío, Sevilla, Spain

- Servicio de Cardiología, Hospital de la Santa Creu i Sant Pau, Barcelona, Spain

$p$ Servicio de Cardiología, Hospital Universitari de Bellvitge, L'Hospitalet de Llobregat, Barcelona, Spain

q Servicio de Cardiología, Hospital Clínic y Provincial de Barcelona, Barcelona, Spain

Servicio de Cardiología, Hospital Universitario Central de Asturias, Oviedo, Asturias, Spain

Servicio de Cardiología, Clínica Universitaria de Navarra, Pamplona, Navarra, Spain

Servicio de Cardiología, Hospital Universitario Miguel Servet, Zaragoza, Spain

Servicio de Cardiología, Hospital Clínico Universitario de Valladolid, Valladolid, Spain

$\checkmark \quad$ Servicio de Cardiología, Hospital Virgen de la Arrixaca, El Palmar, Murcia, Spain

w Instituto Universitario de Ciencias de la Salud, A Coruña, Spain

x Facultad de Medicina, Universitat de València, Valencia, Spain 


\section{Abstract}

\section{Introduction and objectives}

The age of heart transplant recipients and donors is progressively increasing. It is likely that not all donorrecipient age combinations have the same impact on mortality. The objective of this work was to compare survival in transplant recipients according to donor-recipient age combinations.

\section{Methods}

We performed a retrospective analysis of transplants performed between 1 January 1993 and 31 December 2017 in the Spanish Heart Transplant Registry. Pediatric transplants, retransplants and combined transplants were excluded (6505 transplants included). Four groups were considered: a) donor $<50$ years for recipient $<65$ years; b) donor $<50$ years for recipient $\geq 65$ years; c) donor $\geq 50$ years for recipient $\geq 65$ years, and d) donor $\geq 50$ years for recipient $<65$ years.

Results

The most frequent group was young donor for young recipient (73\%). There were differences in the median survival between the groups $(\mathrm{P}<.001)$ : a) younger-younger: 12.1 years, 95\%CI, 11.5-12.6; b) younger-older: 9.1 years, 95\%CI, 8.0-10.5; c) older-older: 7.5 years, 95\%CI, 2.8-11.0; d) older-younger: 10.5 years, 95\%CI, 9.6-12.1. On multivariate analysis, independent predictors of mortality were the age of the donor and the recipient ( 0.008 and 0.001 , respectively). The worst combinations were older-older vs youngeryounger $(\mathrm{HR}, 1.57 ; 95 \% \mathrm{CI}, 1.22-2.01 ; \mathrm{P}<.001)$ and younger-older vs younger-younger $(\mathrm{HR}, 1.33$; 95\% $\mathrm{CI}$, $1.12-1.58 ; \mathrm{P}=.001)$.

\section{Conclusions}

Age (of the donor and recipient) is a relevant prognostic factor in heart transplant. The donor-recipient age combination has prognostic implications that should be identified when accepting an organ for transplant.

\section{Resumen}

Introducción y objetivos

La edad de receptores y donantes cardiacos se está incrementando progresivamente. Es probable que no todas las combinaciones tengan el mismo impacto en la mortalidad. El objetivo de este trabajo es comparar la supervivencia de los pacientes trasplantados según la combinación de edades de donante y receptor.

\section{Métodos}

Análisis retrospectivo del Registro Español de Trasplante Cardiaco de los trasplantes realizados entre el 1 de enero de 1993 y el 31 de diciembre de 2017. Se excluyeron los pediátricos, los retrasplantes y los trasplantes combinados (se incluyeron 6.505 trasplantes). Se consideraron 4 grupos: a) donante menor de 50 años para receptor menor de 65 años; b) donante menor de 50 años para receptor de edad $\geq 65$ años; c) donante de edad $\geq 50$ años para receptor de 65 o más, y d) donante de edad $\geq 50$ años para receptor menor de 65. 


\section{Resultados}

El grupo más frecuente fue el de donante joven para receptor joven (73\%). Hubo diferencias en la mediana de supervivencia entre los grupos ( $<$ 0,001): a) joven-joven: 12,1 años (IC95\%, 11,5-12,6); b) joven-mayor: 9,1 años (IC95\%, 8,0-10,5); c) mayor-mayor: 7,5 años (IC95\%, 2,8-11,0), y d) mayor-joven: 10,5 años (IC95\%, 9,6-12,1). En el análisis multivariante, las edades del donante y del receptor resultaron predictoras independientes de la mortalidad $(0,008$ y 0,001 respectivamente). Las peores combinaciones fueron mayor-mayor frente a joven-joven (HR = 1,57; IC95\%, 1,22-2,01; $\mathrm{p}<0,001$ ) y joven-mayor frente a joven-joven (HR = 1,33; IC95\%, 1,12-1,58; $\mathrm{p}=0,001)$.

\section{Conclusiones}

La edad (del donante y del receptor) es un factor pronóstico relevante en el trasplante cardiaco. La combinación de edades de donante y receptor posee implicaciones pronósticas que se debe conocer a la hora de aceptar un órgano para trasplante.

Keywords

Donor age; Recipient age; Donor/recipient age combinations; Heart transplant; Survival

\section{Palabras clave}

Edad del donante; Edad del receptor; Combinaciones de edad de donante y receptor; Trasplante cardiaco; Supervivencia

\section{Abbreviations}

D, donor; HF, heart failure; HTX, heart transplant; R, recipient 


\section{Introduction}

In recent decades, the age of heart transplant (HTX) recipients has been progressively increasing. $^{1,2,3}$ This is because new drugs and devices for the treatment of heart failure (HF) have delayed the development of advanced HF at older ages. ${ }^{4,5}$ As a consequence, patients reach older ages in better physical and psychological condition. Moreover, greater knowledge of heart preservation and the vast amount of accumulated experience in transplantation has increased the use of hearts from older donors. ${ }^{6,7,8}$

Taking into account the age trend of donors and recipients described in the Spanish Heart Transplant Registry ${ }^{3}$ and in other annual registries, ${ }^{2,9,10}$ it would appear that there has been an increase in the implantation of younger hearts in older patients and vice versa. However, there is a knowledge gap regarding the frequency of these types of implantations, a lack of comparisons between the different groups (younger donor, older donor, younger recipient, older recipient) and between survival rates in these groups, and little information on the actual risk entailed by some of these combinations.

Our working hypothesis was that donor-recipient age combinations have a different impact on survival and that the worst combinations should be identified and possibly not used.

The objective of this study was to analyze the impact of donor-recipient age combinations on survival in HTX recipients.

\section{Methods}

We conducted a retrospective analysis of all transplants performed in Spain between January 1, 1993 and December 31, 2017. Pediatric transplants (under 16 years old), retransplants, and combined transplants (kidney, liver, or lung) were excluded. The final number of transplants was 6505 (figure 1).

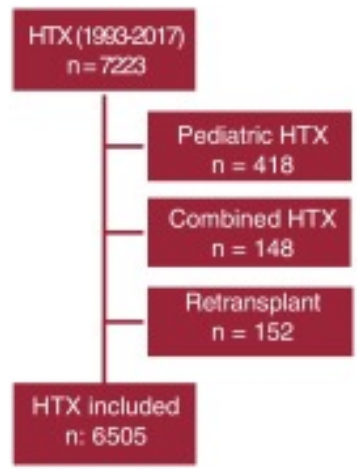

Figure 1. Patient selection algorithm. HTX, heart transplant. 
The data analyzed were obtained from the Spanish Heart Transplant Registry, which includes all transplants performed in Spain (HTX is currently performed in 16 Spanish centers). Transplant data are prospectively entered into an online database. The registry includes more than 100 variables related to recipient, donor, intervention, immunosuppression, and follow-up (table 1 of the supplementary data. The Spanish Heart Transplant Registry is an official registry of the Spanish Ministry of Health and the Spanish Government. The appendix of the supplementary data shows the list of centers and collaborators of the Spanish Heart Transplant Registry. This subanalysis was approved by the Clinical Research Ethics Committee of the Hospital Universitari i Politècnic La Fe (Valencia, Spain).

An older recipient was defined as one more than or equal to 65 years. An older donor was defined as one more than or equal to 50 years. Four combinations were analyzed: younger donoryounger recipient (donor $<50$ years - recipient $<65$ years), younger donor-older recipient (donor $<$ 50 years - recipient $\geq 65$ years), older donor-younger recipient (donor $\geq 50$ years - recipient $<65$ years), and older donor-older recipient (donor $\geq 50$ years - recipient $\geq 65$ years). We also analyzed the predictive variables of mortality.

Variables are expressed as mean \pm standard deviation, or the median [interquartile range] in the absence of normality, and percentages. Differences between groups were analyzed using the chisquare test for qualitative variables and the Kruskal-Wallis test for quantitative variables. Survival curves were calculated using the Kaplan-Meier method and comparisons between them using the log-rank test. Cox proportional hazards model was used to adjust the multivariate model of donorrecipient age groups. In addition to the donor-recipient ages, we initially included variables of known clinical relevance and those that had a $\mathrm{P}$ value greater than 1 in the univariate analysis. Recipient age was included in the model via the combined donor-recipient age variable. Because recipient age is a categorical variable with more than 2 categories, its inclusion in the model entailed its transformation into dummy variables. A dummy variable is a dichotomous (binary) variable that can only take the value 0 or 1 , indicating the absence or presence of a certain characteristic, respectively. The final model was obtained by using a backward procedure to simplify the nonsignificant variables included in the adjustment.

\section{Results}

\section{Distribution of the number of transplants by age group and clinical profile}

We selected 7223 HTXs that were performed between 1993 and 2017 (figure 1). Of these, 418 pediatric transplants, 148 combined transplants, and 152 retransplants were excluded: thus, the final analysis included 6505 HTXs

The proportion of recipients aged more than or equal to 65 years was $10.81 \%$. The proportion of transplant patients with donors more than 50 years was $19.67 \%$. The distribution of the combinations was as follows: donor less than 50 years for recipient less than 65 years, 73\%; donor less than 50 years for recipient more than or equal to 65 years, $7.33 \%$; donor more than or equal to 50 years for recipient less than 65 years, $16.20 \%$; and donor more than or equal to 50 years for recipient more than or equal to 65 years, $3.48 \%$. 


\section{Demographic characteristics of donors and recipients}

Table 1 and table 2 shows the clinical profile of the recipients and donors included in the study. The statistical comparison of the recipients showed that those aged more than or equal to 65 years had more comorbidities (diabetes mellitus and chronic obstructive pulmonary disease), although the percentage of urgent transplants was lower. Nonischemic dilated cardiomyopathy and valvular heart disease were more frequent among younger recipients, whereas ischemic dilated cardiomyopathy was more frequent among older recipients. Urgent transplantation was performed more frequently in recipients younger than 65 years than in older recipients. Thus, there was greater use of short-term ventricular assist devices as a bridge to transplant in younger recipients. This aspect may partly explain the higher prevalence of pretransplant infection in recipients less than 65 years (patients fitted with circulatory/ventricular assist devices with prolonged stays in critical care units). Stroke as a cause of death was more frequent among donors aged more than or equal to 50 years and affected more women than men.

Table 1. Demographic characteristics of the recipients

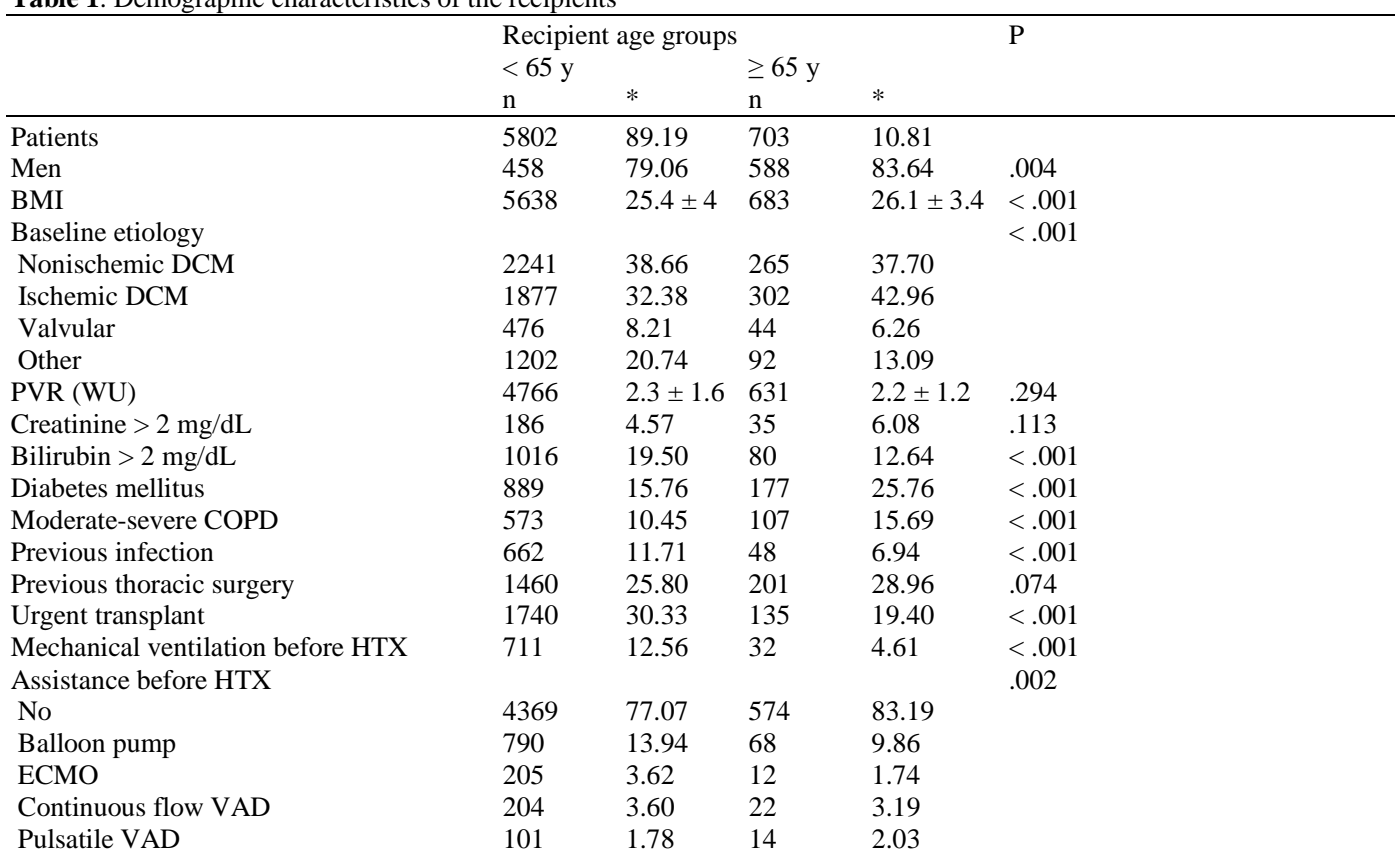

BMI, body mass index; COPD, chronic obstructive pulmonary disease; DCM, dilated cardiomyopathy; ECMO, extracorporeal membrane oxygenation; HTX, heart transplant; PVR, pulmonary vascular resistance; VAD, ventricular assist device; WU, Wood units

P value obtained using the chi-square test and Kruskal-Wallis test.

* Values are expressed as a percentage or mean \pm standard deviation. 
Table 2. Demographic characteristics of donors

\begin{tabular}{|c|c|c|c|c|c|}
\hline & \multirow[b]{3}{*}{$\mathrm{n}$} & \multicolumn{3}{|c|}{ Donor age groups } & \multirow[t]{3}{*}{$\mathrm{P}$} \\
\hline & & $<50 \mathrm{y}$ & $\geq 50 y$ & & \\
\hline & & & $\mathrm{n}$ & $*$ & \\
\hline Patients & 5173 & 80.33 & 1267 & 19.67 & \\
\hline Men & 3651 & 71.03 & 717 & 56.68 & $<.001$ \\
\hline Female donor/male recipient & 1014 & 19.73 & 354 & 27.98 & $<.001$ \\
\hline Weight, kg & 5029 & $73.8 \pm 13.3$ & 1250 & $75.6 \pm 13.2$ & $<.001$ \\
\hline Recipient weight/donor weight & 4980 & $1 \pm 0.25$ & 1244 & $0.98 \pm 0.24$ & .004 \\
\hline Recipient weight/donor weight $>1.20$ & 696 & 13.98 & 122 & 9.81 & $<.001$ \\
\hline Recipient weight/donor weight $<0.8$ & 718 & 14.42 & 192 & 15.43 & .364 \\
\hline BMI & 4894 & $25 \pm 3.7$ & 1224 & $26.6 \pm 3.9$ & $<.001$ \\
\hline Cardiac arrest before transplant & 352 & 10.95 & 62 & 5.68 & $<.001$ \\
\hline Echocardiogram prior to donation & & & & & $<.001$ \\
\hline Not performed & 617 & 13.46 & 45 & 3.80 & \\
\hline Normal & 3894 & 84.95 & 1117 & 94.26 & \\
\hline Mild general dysfunction & 73 & 1.59 & 23 & 1.94 & \\
\hline Cause of death & & & & & $<.001$ \\
\hline Cerebrovascular & 2094 & 41.56 & 929 & 73.85 & \\
\hline Trauma & 2377 & 47.17 & 208 & 16.53 & \\
\hline Other & 568 & 11.27 & 121 & 9.62 & \\
\hline
\end{tabular}

BMI, body mass index

$P$ value obtained using the chi-square test and Kruskal-Wallis test.

* Values are expressed as a percentage or mean \pm standard deviation.

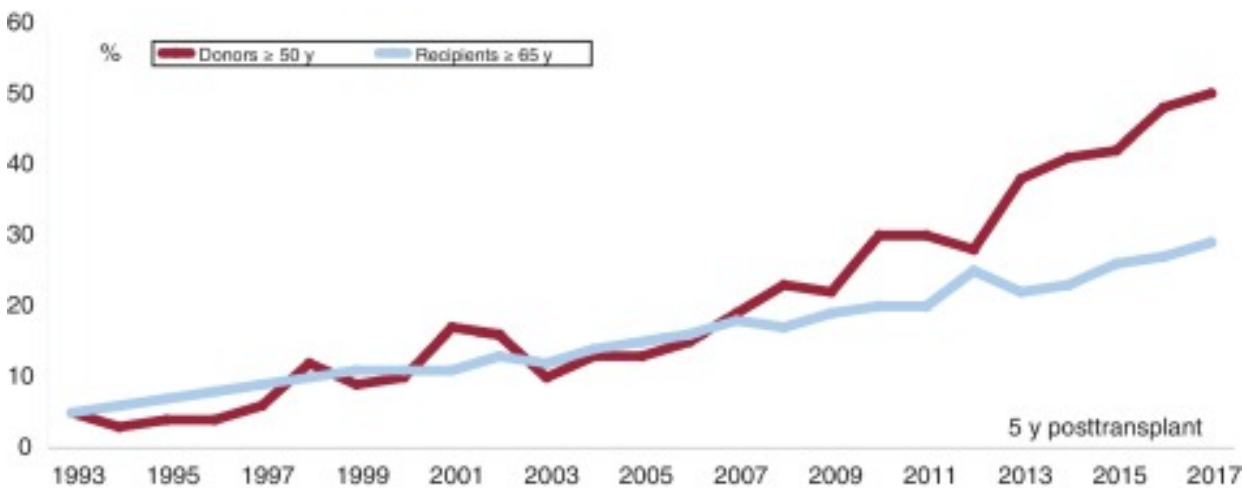

Figure 2. Percentages of recipients older than or equal to 65 years and donors aged older than or equal to 50 years of all recipients and donors for each year (1993-2017).

\section{Distribution of age groups by year}

Figure 2 shows the percentage of recipients and donors in relation to total transplants each year. There was a gradual increase in both groups. However, from 2007 onward, the increase was no longer proportional as the progression curves began to separate. 


\section{Survival by age group}

Table 3 and table 4 show the probability of survival by age group, median survival, and confidence intervals over the entire follow-up period. The median survival of recipients less than 65 years was 12 years, whereas that of recipients more than or equal to 65 years was 8.7 years. However, the median survival of donors less than 50 years was 11.8 years, whereas that of donors more than or equal to 50 years was 10.3 years.

Table 3. Probability of survival (P) and median survival by recipient age

\begin{tabular}{|c|c|c|c|c|c|c|}
\hline \multirow{3}{*}{$\begin{array}{l}\text { Time } \\
30 \mathrm{~d}\end{array}$} & \multicolumn{3}{|c|}{$<65 y$} & \multicolumn{3}{|c|}{$\geq 65 y$} \\
\hline & \multirow{2}{*}{$\begin{array}{l}\mathbf{P} \text { \% } \\
86.2\end{array}$} & \multicolumn{2}{|c|}{$95 \%$ CI } & \multirow{2}{*}{$\begin{array}{l}\mathbf{P} \% \\
87.2\end{array}$} & \multicolumn{2}{|c|}{$95 \%$ CI } \\
\hline & & 85.3 & 87.1 & & 84.5 & 89.5 \\
\hline 3 mo & 82.3 & 81.3 & 83.2 & 82.1 & 79.0 & 84.7 \\
\hline $6 \mathrm{mo}$ & 80.3 & 79.2 & 81.3 & 79.5 & 76.3 & 82.3 \\
\hline $1 \mathrm{y}$ & 77.9 & 76.8 & 79.0 & 76.8 & 73.5 & 79.7 \\
\hline $5 \mathrm{y}$ & 67.6 & 66.4 & 68.8 & 64.7 & 61.0 & 68.2 \\
\hline $10 \mathrm{y}$ & 55.4 & 54.0 & 56.8 & 47.1 & 42.8 & 51.3 \\
\hline $15 \mathrm{y}$ & 40.7 & 39.1 & 42.2 & 25.3 & 20.8 & 30.0 \\
\hline $20 \mathrm{y}$ & 28.2 & 26.5 & 29.9 & 10.7 & 6.5 & 16.1 \\
\hline Median, y & 12.0 & 11.4 & 12.4 & 8.7 & 7.9 & 10.2 \\
\hline
\end{tabular}

95\%CI, 95\% confidence interval by recipient age group.

At 10 years, 15 years, and 20 years after transplant, the percentage of recipients younger than 65 years and older than or equal to 65 years falls to $65 \%$ and $49.8 \%$ (10 years), $33 \%$ and $17.7 \%$ (15 years), and $11 \%$ and $2.9 \%$ (20 years), respectively.

Table 4. Probability of survival (P) and median survival by donor age

\begin{tabular}{|c|c|c|c|c|c|c|}
\hline \multirow{3}{*}{$\frac{\text { Time }}{30 \mathrm{~d}}$} & \multicolumn{3}{|c|}{$<50 \mathrm{y}$} & \multicolumn{3}{|c|}{$\geq 50 y$} \\
\hline & \multirow{2}{*}{$\begin{array}{l}\mathbf{P}(\mathbf{\%}) \\
86.7\end{array}$} & \multicolumn{2}{|c|}{$95 \%$ CI } & \multirow{2}{*}{$\begin{array}{l}\mathbf{P}(\mathbf{\%}) \\
85.1\end{array}$} & \multicolumn{2}{|c|}{$95 \%$ CI } \\
\hline & & 85.7 & 87.6 & & 83.0 & 86.9 \\
\hline $3 \mathrm{mo}$ & 82.9 & 81.9 & 83.9 & 79.9 & 77.6 & 82.0 \\
\hline $6 \mathrm{mo}$ & 80.8 & 79.7 & 81.9 & 78.0 & 75.6 & 80.2 \\
\hline $1 \mathrm{y}$ & 78.4 & 77.3 & 79.5 & 75.6 & 73.2 & 77.9 \\
\hline $5 y$ & 67.5 & 66.2 & 68.8 & 66.8 & 64.0 & 69.4 \\
\hline $10 \mathrm{y}$ & 55.1 & 53.6 & 56.5 & 51.0 & 47.4 & 54.5 \\
\hline $15 \mathrm{y}$ & 39.8 & 38.3 & 41.4 & 35.0 & 30.6 & 39.5 \\
\hline $20 \mathrm{y}$ & 27.3 & 25.6 & 29.0 & 22.3 & 17.0 & 28.1 \\
\hline Median, y & 11.8 & 11.3 & 12.3 & 10.3 & 9.2 & 11.2 \\
\hline
\end{tabular}

95\%CI, 95\% confidence interval by donor age group.

At 10 years, 15 years, and 20 years after transplant, the percentage of recipients less than 65 years and older than or equal to 65 years falls to $65 \%$ and $49.8 \%$ (10 years), 33\% and $17.7 \%$ (15 years), and $11 \%$ and $2.9 \%$ (20 years), respectively. 
Figure 3 shows the survival curves of the recipients and donors grouped by age. During the time period shown, the survival curves gradually separated and reached statistical significance.
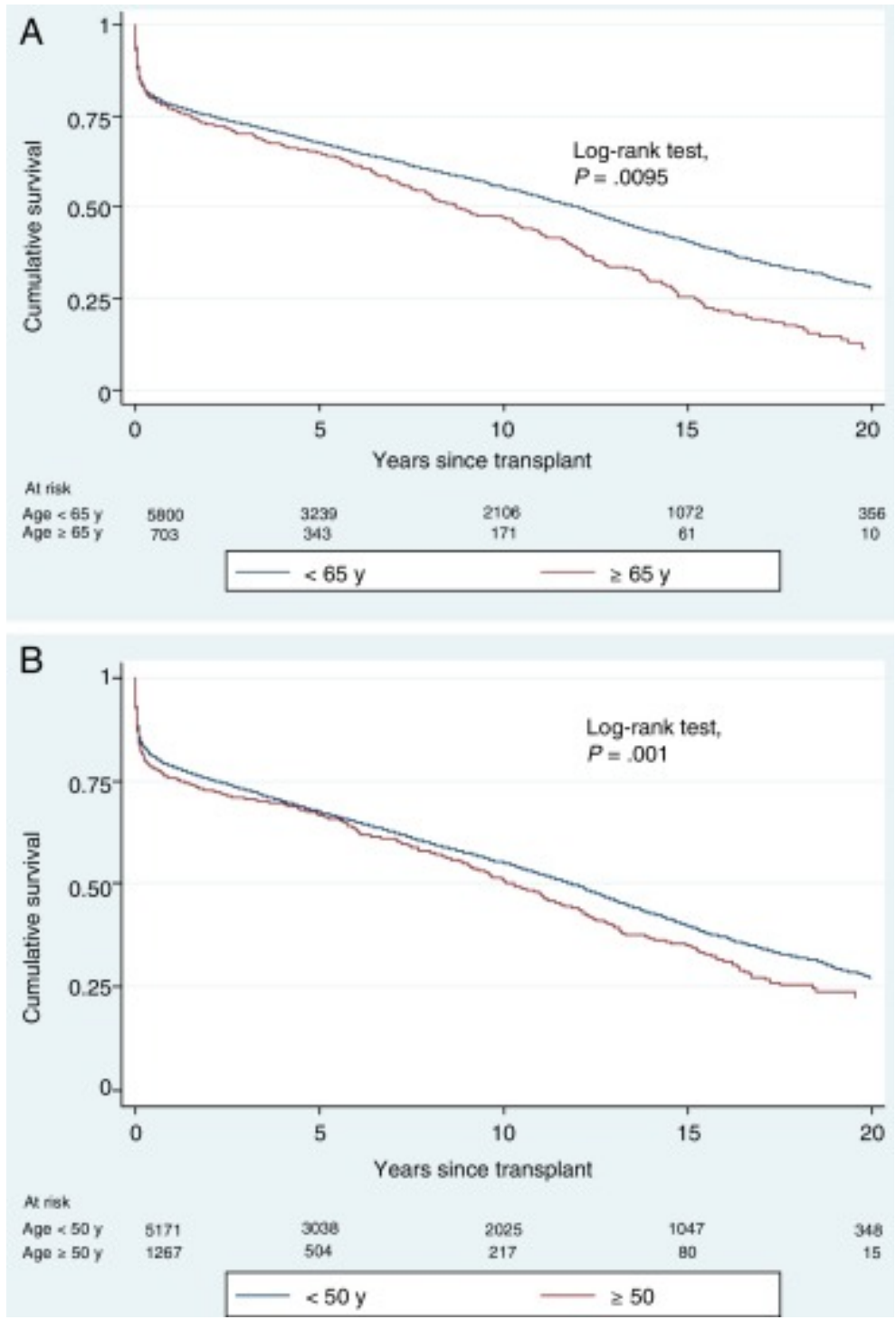

Figure 3. Analysis of the influence of age on survival (in both figure parts death is the final outcome). A, comparison of recipients younger than 65 years and recipients older than or equal to 65 years. Log-rank test, $\mathrm{P}=.0095$. $\mathrm{B}$, comparison of donors younger than 50 years and donors older than or equal to 50 years. Log-rank test, $\mathrm{P}<.001$. 


\section{Causes of death}

Table 5 shows the distribution of the main causes of death of recipients by donor-recipient age groups.

Table 5. Distribution (\%) of the main causes of death of recipients by donor-recipient age group

\begin{tabular}{llllll}
\hline & \multicolumn{3}{c}{ Donor-recipient age groups } & \multirow{2}{*}{ Total (n= 3540) } \\
\cline { 2 - 5 } & $\begin{array}{l}\text { Younger-younger } \\
\mathbf{( n = 2 6 8 4 )}\end{array}$ & $\begin{array}{l}\text { Younger-older } \\
\mathbf{( n = 2 9 0 )}\end{array}$ & $\begin{array}{l}\text { Older-older } \\
(\mathbf{n = 1 1 4})\end{array}$ & Older-younger $(\mathbf{n}=\mathbf{4 5 2})$ & \\
\hline Primary failure & 11.14 & 10.69 & 16.67 & 18.36 & 12.20 \\
\hline Acute rejection & 5.89 & 4.14 & 6.14 & 6.19 & 5.79 \\
\hline Chronic rejection & 7.15 & 4.14 & 1.75 & 4.65 & 6.41 \\
\hline Infection & 16.17 & 19.66 & 20.18 & 19.91 & 17.06 \\
\hline Cancer & 15.05 & 18.62 & 11.40 & 13.27 & 15.00 \\
\hline Cardiac arrest & 7.56 & 4.48 & 6.14 & 4.87 & 6.92 \\
\hline Multiorgan failure & 5.25 & 7.24 & 5.26 & 5.31 & 5.42 \\
\hline Other & 31.78 & 31.03 & 32.46 & 27.43 & 31.19 \\
\hline Total & 100 & 100 & 100 & 100 & 100 \\
\hline
\end{tabular}

\section{Analysis of combinations}

Table 6 shows the probability of short-, mid-, and long-term survival of recipients in 4 age groups (age $<65$ years, 65-67 years, 68-70 years, and $>70$ years). Long-term survival decreased as the age of the recipients increased. Table 7 shows the probability of survival in the 4 study groups. The probability of survival was highest in the younger donor-younger recipient combination and lowest in the older donor-older recipient combination. Of the other 2 combinations, the probability of survival was highest in the older donor-younger recipient. Figure 4 compares actuarial survival between recipient age groups and between the 4 donor-recipient combinations (log-rank test).

Table 6. Probability of survival (P) with 95\% confidence interval by recipient age groups

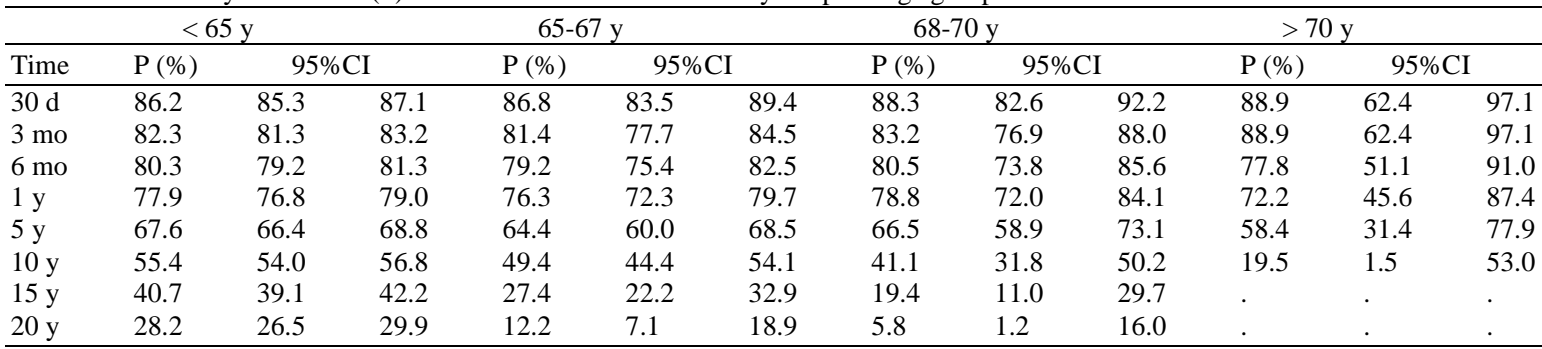

95\%CI, 95\% confidence interval. 
Table 7. Probability of survival (P) with 95\% confidence interval by donor-recipient age combinations

\begin{tabular}{|c|c|c|c|c|c|c|c|c|c|c|c|c|}
\hline & \multicolumn{3}{|c|}{ Younger-younger } & \multicolumn{3}{|c|}{ Younger-older } & \multicolumn{3}{|c|}{ Older-older } & \multicolumn{3}{|c|}{ Older-younger } \\
\hline \multirow{2}{*}{$\frac{\text { Time }}{30 \mathrm{~d}}$} & \multirow{2}{*}{$\begin{array}{l}\mathrm{P}(\%) \\
86.6\end{array}$} & \multicolumn{2}{|c|}{$95 \% \mathrm{CI}$} & \multirow{2}{*}{$\begin{array}{l}\mathrm{P}(\%) \\
87.7\end{array}$} & \multicolumn{2}{|c|}{$95 \% \mathrm{CI}$} & \multirow{2}{*}{$\begin{array}{l}\text { P (\%) } \\
87.1\end{array}$} & \multicolumn{2}{|c|}{$95 \% \mathrm{CI}$} & \multirow{2}{*}{$\begin{array}{l}\text { P (\%) } \\
84.6\end{array}$} & \multicolumn{2}{|c|}{$95 \% \mathrm{CI}$} \\
\hline & & 85.6 & 87.5 & & 84.4 & 90.4 & & 81.9 & 90.8 & & 82.3 & 86.7 \\
\hline $3 \mathrm{mo}$ & 82.9 & 81.8 & 83.9 & 83.2 & 79.6 & 86.3 & 80.4 & 74.5 & 85.0 & 79.8 & 77.2 & 82.1 \\
\hline $1 \mathrm{y}$ & 78.5 & 77.3 & 79.6 & 77.7 & 73.7 & 81.2 & 75.5 & 69.3 & 80.6 & 75.7 & 72.9 & 78.2 \\
\hline $5 y$ & 67.6 & 66.2 & 69.0 & 66.2 & 61.7 & 70.3 & 61.3 & 54.0 & 67.8 & 68.0 & 64.9 & 70.8 \\
\hline $10 \mathrm{y}$ & 55.7 & 54.2 & 57.2 & 48.0 & 42.9 & 52.9 & 45.3 & 36.7 & 53.4 & 52.2 & 48.2 & 56.1 \\
\hline $20 \mathrm{y}$ & 28.5 & 26.7 & 30.3 & 11.9 & 7.2 & 17.9 & . & . & . & 25.3 & 19.3 & 31.7 \\
\hline
\end{tabular}

95\%CI, 95\% confidence interval.

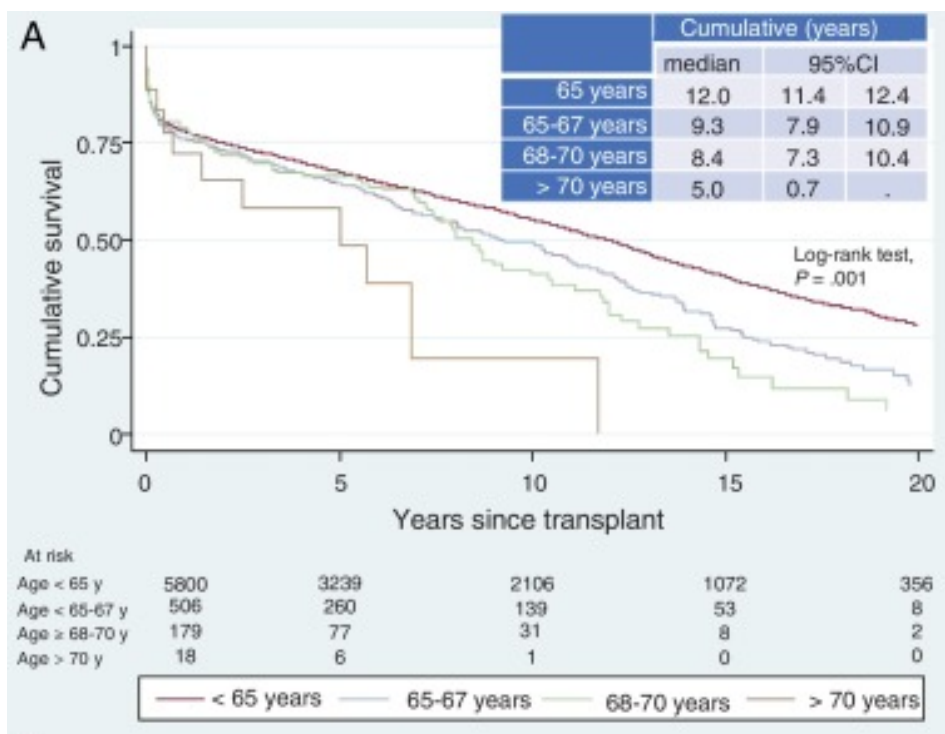

B

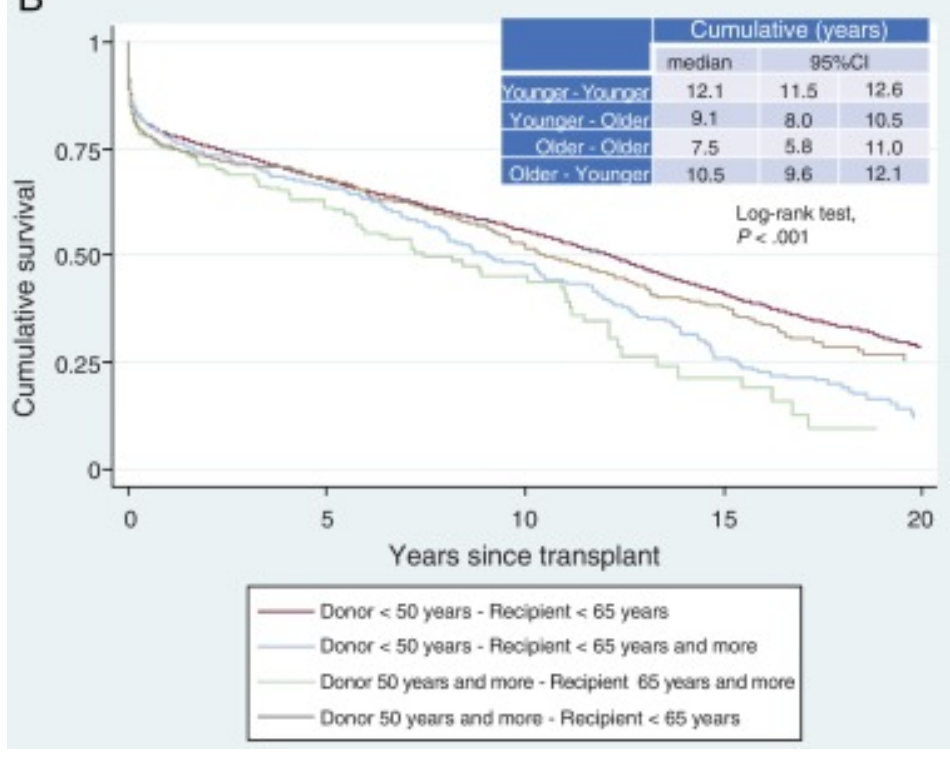

Figure 4. Analysis of the influence of age and the recipient-donor combination on survival (in both figure parts death is the final outcome). A, comparison by recipient age. Log-rank test, $\mathrm{P}<.001$. B, comparison of recipient-donor age combinations. Log-rank test, $\mathrm{P}<.001$. 95\%CI, 95\% confidence interval. 


\section{Multivariate analysis}

Table 2 of the supplementary data shows Cox univariate analysis for the mortality outcome. Table 8 shows the final adjusted multivariate model of mortality outcome. In HTX patients, many variables are associated with mortality. In both the donor and recipients, increased age was linearly related to increased mortality. Furthermore, after adjustment for other significant variables, all donor-recipient age combinations were independent predictors of mortality in relation to the best combination (ie, younger donor-younger recipient).

Table 8. Multivariate analyses effect of donor and recipient age on mortality

\begin{tabular}{lllll}
\hline Variable $^{\mathrm{a}}$ & $\mathrm{HR}^{\mathrm{b}}$ & \multicolumn{2}{c}{ 95\%CI } & $\mathrm{P}$ \\
\hline Younger donor-older recipient (young-older vs young-younger) & 1.38 & 1.16 & 1.64 & $<.001$ \\
Older donor-older recipient & 1.62 & 1.23 & 2.13 & .001 \\
Older donor-younger recipient & 0.98 & 0.81 & 1.18 & .845 \\
\hline
\end{tabular}

95\%CI, 95\% confidence interval; HR, hazard ratio.

${ }^{\text {a}}$ The comparison group is always younger donor-younger recipient.

${ }^{\mathrm{b}}$ Final multivariate model adjusted for diabetes mellitus, kidney failure, previous sternotomy, mechanical ventilation, extracorporeal circulation time, induction, primary graft failure, dialysis, infection in the first year, cancer (skin cancer vs none and nonskin cancer vs none), and year of transplant.

\section{Discussion}

In the first decades of HTX, only people younger than 35 years were accepted as donors. ${ }^{11,12,13}$ However, as waiting lists grew and there was an urgent need for more hearts as soon as possible, ${ }^{14}$ transplant teams began to accept hearts from more donors. ${ }^{3,15,16}$ In addition, until relatively few years ago, HTX was exclusively restricted to recipients aged up to 50 years. However, in recent decades, the age of recipients has increased and the selection criteria have been expanded. 1, 17, 18, 19 These changes have been due to advances in surgical techniques, major improvements in postoperative treatment, and above all, new treatments and devices for HF that improve the quality and quantity of life, thus allowing these patients to reach older ages in good health. ${ }^{20,}{ }^{21}$ In addition, in recent decades, there has been progressive improvement in the treatment of diseases that may ultimately lead to ischemic HF (ie, the generalized use of primary angioplasty programs), valvular HF, cardiotoxicity, and so on. These improvements delay the onset and development of HF, thus shifting upward the age at which HTX is indicated. Therefore, since the beginning of HTX, donor and recipient age has also progressively increased. This trend may also be related to greater experience in THX. However, as of 2007, the progression curves separated and the proportion of donors older than 50 years increased annually much more than that of recipients older than 65 years. Thus, the annual proportion of donors older than 50 years old exceeded $50 \%$. It is not clear what could have happened in that year, but it may have been the case that the greater demand due to longer waiting lists, the increase in urgent transplants, and more experience in donor selection led to the view that the older age of these donors was no longer considered to be an excessive risk to survival. Currently, all transplant teams accept donors above this age. The latest HTX register from the International Society for Heart and Lung Transplantation (ISHLT) also shows that from 2009 to 2017 there was a progressive increase in the age of donors. ${ }^{22}$ 
There are few scientific studies on the impact of this trend. Although the ISHLT guidelines recommended increasing the age of potential recipients to 70 years in $2006,{ }^{23}$ many hospitals still consider age to be a limiting factor for HTX in patients with advanced HF. Data from the Spanish Heart Transplant Registry ${ }^{3}$ may clarify the relationship between donor-recipient age and survival. For all these reasons, this study analyzed the impact of 4 donor-recipient age combinations on HTX survival. The 4 groups comprised younger donor to younger/older recipient and older donor to a younger/older recipient. The results showed that there was a difference in survival between the 4 groups. The best combination was younger donor-younger recipient and the worst combination was older donor-older recipient. However, the results from other 2 groups are those with the greatest interest from the point of view of clinical practice.

We followed the previous literature to determine the cutoff point to consider a donor as older, because several studies have shown that a donor age of more than 50 years is associated with an increased risk of posttransplant mortality. ${ }^{7}{ }^{24}$ Other studies have used cutoff points of 50 years or more and less than 40 years to consider donors as older and younger, respectively. Donors aged 40 to 49 years were excluded from the analyses to obtain a clearer distinction between the 2 groups. $^{25}$ However, given the significant percentage of donors in this interval, we used a cutoff point of 50 years to include the entire spectrum of donors. Thus, the results of the analysis are more relevant from a clinical perspective and may assist in decision-making in real-world settings.

In Spain, $11 \%$ of patients who undergo HTX are older than 65 years. In these recipients, the most frequent cause of heart disease is of ischemic origin and the prevalence of comorbidities is higher; however, the proportion of urgent transplants and mechanical ventilation is lower. This profile is similar to that reported in previous studies, especially in relation to the higher prevalence of comorbidities and ischemic heart disease in this group of recipients. A steady trend (typically nonsignificant) has been observed toward a lower percentage of these patients undergoing urgent HTX. $^{26}$

In the present study, $20 \%$ of the donors were older than 50 years and a higher percentage of women died from nontraumatic cerebrovascular causes. However, the recipient/donor weight ratio was better in the previous study. ${ }^{26}$ The aforementioned profile is similar to that reported in some registries, ${ }^{15,25}$ in which stroke was the most frequent cause of death in donors more than or equal to 50 years; however, the percentage of female donors in this group was not high.

The distribution of donor-recipient age groups shows that the number of patients differed in each group. The most frequent group was younger donor for younger recipient (73\%) followed by older donor for younger recipient (16.2\%). The Spanish Heart Transplant Registry3 database was used to obtain a sufficient number of patients in the less frequent groups (younger donor for older recipient [7.3\%] and older donor for older recipient [3.5\%]). This registry includes all the HTXs performed in Spain from the first one in May 1984 to the present and is completed by all the Spanish HTX teams.

Significant differences were found between transplants in older and younger recipients, with a difference of almost 3.5 years in median survival (12 years vs 8.7 years, respectively). An association was also found between an increase in the age of the recipients and a decrease in their probability of survival. In fact, in recipients older than 70 years, the probability of post-HTX 10year survival was only $19.5 \%$. However, there were no differences between recipient groups in early mortality. Thus, the survival curves were identical at the beginning and then began to gradually separate. This finding could be explained by expected survival time based on the age of the recipients independently of the transplant. It could also lead to the age of the recipient not being considered as the only criterion by which HTX could be contraindicated. 
Differences were also found in median survival between donors and recipients older and younger than 50 years (11.8 years vs 10.3 years, respectively). In this case, however, the difference was 1.5 years. It therefore appears that donor age is not as relevant as recipient age as a cause of long-term mortality. The survival curve shows that the initial fall, which is related to the perioperative process, was greater when the donors were older. Subsequently, the curves tended to separate slightly, then from 5 years onward the separation clearly widened consistently over time. The scientific literature typically considers donor age to be an independent risk factor for mortality in $\mathrm{HTX}^{27,}{ }^{28}$ although there are conflicting data. Data from the most recently published ISHLT registry $^{11}$ and the United Network for Organ Sharing ${ }^{29}$ database show that advanced donor age increases the risk of mortality for all recipients. However, a Spanish study published in 2015 found no difference in mortality in older donors after adjusting for confounding factors, although it found a mid-term increase in the risk of vascular graft disease in older donors.

The present study found differences between donor-recipient age combinations. The worst mean survival time was found in the older donor-older recipient age combination ( 7.5 years). The other 3 combinations initially showed similar survival curves; however, from the fifth year onward the gap between curves began to widen. Thus, mean survival time was 12.1 years in the youngeryounger combination, 10.5 years in the older-younger combination, and 9.1 years in the youngerolder combination. The results show survival would be reduced in each risk combination by approximately 1.5 years in relation to the best combination (younger-younger, 12 years). A study published in 2020 assessed the relationship between donor and recipient age by dividing recipients into those younger than 60 years vs those older than or equal to 60 years and donors younger than 50 years vs those older than or equal to 50 years. Five-year survival was significantly lower among recipients who received an older heart than among those who received a younger heart (67\% vs $73 \%$ respectively; log-rank test, $\mathrm{P}<.001)^{23}$

Multivariate analysis confirmed the relevance of donor-recipient age to survival. Thus, the risk of mortality was 32\% higher in recipients older than 65 years than in recipients younger than 65 years. Furthermore, there were significant differences in survival between the best age combination (younger donor-younger recipient) and all the other combinations, except for one: there were no significant differences in survival between the older donor-younger recipient combination and the younger donor-younger recipient combination. This may make individuals older than or equal to 55 years suitable donors even for younger recipients without it being a predictor of worse survival. Furthermore, significance was maintained after adjustnebt if the variables with those that reached significance in the univariate analysis and that are known to be associated with posttransplant mortality. ${ }^{30,31}$ However, the option of transplanting older hearts into older patients (worst combination) should not be rejected, because in these patients survival times are much longer than those in patients older than 65 years with advanced HF. ${ }^{32,33}$

\section{Limitations}

This study has the limitations associated with the use of databases; although main variables are entered prospectively, the analysis and inclusion of secondary variables can be retrospective. However, in the present study, the main variables were fixed, were not subject to defining criteria, were $100 \%$ complete, and could not give rise to confusion. Therefore, the results of this study have a high level of reliability and show real trends. Moreover, the present study was a multicenter study of all HTXs performed in the inclusion period in which all Spanish HTX teams participated. These characteristics also ensure that the results have a high level of reliability and are representative of the real situation in Spain, where there is a highly developed HTX organization system. This study also shows that although few older hearts are implanted, they do not reduce survival time by very much, particularly when they are implanted in younger recipients. Further research could investigate whether the donor pool could be increased and determine the research strategies to be conducted by the HTX groups and the Spanish National Transplant Organization. 


\section{Conclusions}

The results of the present study suggest that the age of the donor and recipient is a relevant prognostic factor in HTX. The donor-recipient age combination has prognostic implications that must be known and weighed up when accepting an organ for transplant.

\section{Conflicts of interest}

None declared.

\section{References}

1. Mehra MR, Canter CE, Hannan MM, et al. The 2016 International Society for HeartLung Transplantation listing criteria for heart transplantation: a 10-year update..J Heart Lung Transplant. 2016;35:1-23.

2. Lund LH, Edwards LB, Dipchand AI, et al. The Registry of the International Societyfor Heart and Lung Transplantation: Thirty-third Adult Heart Transplantation Report-2016; Focus Theme: Primary Diagnostic Indications for Transplant. J Heart Lung Transplant. 2016;35:1158-1169.

3. González-Vílchez F, Almenar Bonet L, Crespo-Leiro MG, et al. Registro Español deTrasplante Cardiaco. XXIX Informe Oficial de la Sección de Insuficiencia Cardiaca de la Sociedad Española de Cardiología (1984-2017). Rev Esp Cardiol. 2018;71:952-960.

4. Nieminen MS, Dickstein K, Fonseca C, et al. The patient perspective: quality of life in advanced heart failure with frequent hospitalisations. Int J Cardiol. 2015;191:256-264.

5. Crespo-Leiro MG, Metra M, Lund LH, et al. Advanced heart failure: a position statement of the Heart Failure Association of the European Society of Cardiology. Eur J Heart Fail. 2018;20:1505-1535.

6. Lund LH, Edwards LB, Kucheryavaya AY, et al. The Registry of the International Society for Heart and Lung Transplantation: Thirty-second Official Adult Heart Transplantation Report-2015; Focus Theme: Early Graft Failure. J Heart Lung Transplant. 2015;34:1244-1254.

7. Reich HJ, Kobashigawa JA, Aintablian T, Ramzy D, Kittleson MM, Esmailian F. Effects of older donor age and cold ischemic time on long-term outcomes of heart transplantation. Tex Heart Inst J. 2018;45:17-22.

8. Roig E, Almenar L, Crespo-Leiro M, et al. Heart transplantation using allografts from older donors: Multicenter study results. J Heart Lung Transplant. 2015;34:790-796.

9. Kobashigawa J, Khush K, Colvin M, et al. Report from the American Society of Transplantation Conference on Donor Heart Selection in Adult Cardiac Transplantation in the United States. Am J Transplant. 2017;17:2559-2566.

10. Zijlstra LE, Constantinescu A, Manintveld O, et al. Heart transplantation in the 21st century in Netherlands: improved survival in the last decade. Ned Tijdschr Geneeskd. 2015;159:A9346.

11. Heck CF, Shumway SJ, Kaye MP. The Registry of the International Society for Heart Transplantation: sixth official report-1989. J Heart Transplant. 1989;8:271-276.

12. Griepp RB, Stinson EB, Clark DA, Dong Jr E, Shumway NE. The cardiac donor. Surg Gynecol Obstet. 1971;133:792-798.

13. Menkis AH, Novick RJ, Kostuk WJ, et al. Successful use of the "unacceptable” heart donor. J Heart Lung Transplant. 1991;10:28-32.

14. Dorent R, Cantrelle C, Jasseron C, Legeai C. Heart transplantation in France: Current status. Presse Med. 2014;43:813-822.

15. Guihaire J, Noly PE, Martin A, et al. Impact of donor comorbidities on heart transplant outcomes in the modern era. Interact Cardiovasc Thorac Surg. 2017;24:898-904. 
16. Bruschi G, Colombo T, Oliva F, et al. Orthotopic heart transplantation with donors greater than or equal to 60 years of age: A single-center experience. Eur J Cardiothorac Surg. 2011;40:e55-e61.

17. Smits JM. Unlocking the potential of organ donation. Am J Transplant.2017;17:25032504.

18. Samsky MD, Patel CB, Owen A, et al. Ten-year experience with extended criteria cardiac transplantation. Circ Heart Fail. 2013;6:1230-1238.

19. Felker GM, Milano CA, Yager JE, et al. Outcomes with an alternate list strategy for heart transplantation. J Heart Lung Transplant. 2005;24:1781-1786.

20. Cowger J, Shah P, Stulak J, et al. Intermacs profiles and modifiers: heterogeneity of patient classification and the impact of modifiers on predicting patient outcome..J Heart Lung Transplant. 2016;35:440-448.

21. Miller L, Birks E, Guglin M, et al. Use of ventricular assist devices and heart transplantation for advanced heart failure. Circ Res. 2019;24:1658-1678.

22. Khush KK, Cherikh WS, Chambers DC, et al. The International Thoracic Organ Transplant Registry of the International Society for Heart and Lung Transplantation: Thirty-fifth Adult Heart Transplantation Report-2018; focus theme: multi-organ transplantation. J Heart Lung Transplant. 2018;37:1155-1168.

23. Mehra MR, Kobashigawa J, Starling R, et al. Listing criteria for heart transplantation: International Society for Heart and Lung Transplantation guidelines for the care of cardiac transplant candidates-2006. J Heart Lung Transplant. 2006;25:1024-1042.

24. Daniel M, Chen C, Chung J, Goldberg L, Acker MA, Atluri P. Interaction of donor and recipient age: do older heart transplant recipients require younger hearts? Ann Thorac Surg. 2019;107:62-66.

25. Prieto D, Correia P, Baptista MA, Antunes MJ. Outcome after heart transplantation from older donor age: expanding the donor pool. Eur J Cardiothorac Surg.2015;47:672-678.

26. Jamil A, Qin H, Felius J, et al. Comparison of clinical characteristics, complications,and outcomes in recipients having heart transplants $<65$ years of age versus $\square 65$ years of age. Am J Cardiol. 2017;120:2207-2212

27. Morgan JA, John R, Weinberg AD, et al. Long term results of cardiac transplantationin patients 65 years of age and older: a comparative analysis. Ann Thorac Surg.2003;76:1982-1987.

28. Kilic A, Emani S, Sai-Sudhakar CB, Higgins RS, Whitson BA. Donor selection in heart transplantation. J Thorac Dis. 2014;6:1097-1104.

29. Hong KN, Iribarne A, Worku B, et al. Who is the high-risk recipient? Predicting mortality after heart transplant using pretransplant donor and recipient risk factors. Ann Thorac Surg. 2011;92:520-527.

30. Foroutan F, Alba AC, Guyatt G, et al. Predictors of 1-year mortality in heart transplant recipients: a systematic review and meta-analysis. Heart.2018;104:151-160.

31. Paniagua MJ, Almenar-Bonet L, Palomo J, et al. Influencia del perfil clínico del donante, receptor y tiempo de isquemia en la supervivencia del trasplante cardiaco. Subanálisis del Registro Español de Trasplante Cardiaco. Cir Cardiov.2015;22:279-286.

32. Long JW, Kfoury AG, Slaughter MS, et al. Long-term destination therapy with the HeartMate XVE left ventricular assist device: improved outcomes since the RE-MATCH study. Congest Heart Fail. 2005;11:133-138.

33. Daneshmand MA, Krishnamoorthy A, Samsky MD, et al. Comparison of 2-year outcomes of extended criteria cardiac transplantation versus destination left ventricular assist device therapy using continuous flow. Am J Cardiol.2015;116:573-579. 